\title{
FARM SIZE AND PRODUCTIVITY OF FOOD CROP FARMERS IN ABEOKUTA NORTH LOCAL
}

\section{GOVERNMENT AREA, OGUN STATE, NIGERIA}

Akerele, Ezekiel Olaoluwa; Babayanju, Damilola Tobi; and Oyebanjo, Olumayowa. Department of Agricultural Economics and Farm Management

Faculty of Agricultural Management and Rural Development College of Agricultural Sciences Olabisi Onabanjo University, Yewa Campus, Ayetoro, Ogun State, Nigeria

e-mail: akereleeze@gmail.com

\section{ABSTRACT}

This study examined farm size and productivity of food crop farmers in Abeokuta North Local Government Area of Ogun State, Nigeria. The study was based on primary data obtained through the use of structured questionnaires. The survey involved a cross section random selection of 112 farming households from the study area. Data were obtained on the socio - economic characteristic of the farming members of the households, mode of land acquisition, parcels of land available for cultivation, total parcels of land cultivated, resources used, cost and outputs of food crops on parcels
of land cultivated. The data was analyzed by both descriptive statistics and stochastic frontier model of land cultivated. The data was analyzed by both descriptive statistics and stochastic frontier mode
with the level of land fragmentation measured by Simpson index as well as the number of parcel with the level of land fragmentation measured by Simpson index as well as the number of parcel
cultivated. It was found that significant evidence exists to show that most farms cultivated in the study area are relatively fragmented which was caused by inheritance mode of land acquisition and this have effect on food crop production. The farm sizes cultivated by farming households have significance effect on output. Hired labour and cost of intermediate materials used have significant effect on the production efficiency of farmers. The finding revealed that most farming households in the study area
were found operating relatively on scattered farm land. On the basis of the above findings, it was recommended that Farmers' accessibility to loans should be addressed by government and to establis farm estate, pattern of land holding and also acquisition of more farmland should be addressed for high production efficiency.

Keywords: Farm Size, Productivity, Food Crop Farmers, Ogun State, Nigeria

Accepted date: 9 June 2020

\section{INTRODUCTION}

Agriculture has been the only occupation that employs the majority of Nigerian population, about 70 percent (DFID 2004). Before the advent of crude oil exploitation, agriculture was the major source of foreign exchange earnings for the country. The south-western part of the country was known for their cocoa production, northern part of the country for their groundnut pyramid, while the eastern part of the country was known for their palm oil production. The discovery of crude oil and the returns made from it led to total neglect and decay of agricultural sector in the country. Many fund and activities, as well as policies had been affected by government and concerned NGOs to resuscitate the hailing agricultural sector but all their actives and actions have always proved abortive.

Presently nothing seems working in the agricultural sectors. The country dream for food security has ended up being a mirage, (Durojaye, 2001) in his own submissio made it known that heproducton of stable food in Nigeri has continue to fall shot of the rate of growth in her population. The interpretation of this is that the country is experiencing fast population growth and the level of agricultural activities cannot feed the population. In this prevailing scenario agricultural products importation inevitable. The inadequacy of the local agricultura markets to provide raw materials to he nations agricultura industries, reducing the infrastructure and amenities for mass unemployment in the country. Agricultural land exploitation in Nigeria he never been encouraging, and this is because the large percentage of the farming population is made up of small 
scale and peasant farmers who farm on small portion of lands to provide food for their families and to sell the (a) only access limited land for farming makes it diffice can them to practice modern agricultural practices (ie. mechanized farming), and this has been the basis for their low productivity. Nigeria is one the few newly industrialized third world nations whose growth rate in the last two decades has been estimated to 12.8 between 199098 and 17.65 (1999-98), (Famoriyo, 1996). Nigeria is, however, an agrarian nation with over $56.8 \%$ of her working force engaged in farming (Afolayan, 1998). The importance of this sector in the overall economic development of Nigeria can, therefore, not be overemphasized. Doner and Kanel (1997) emphasized the significant contribution of the agricultural sector towards the overall economic development of underdeveloped countries where more than $50 \%$ of the working population is engaged in farming. Many factors in recent times have continued to posse challenges to the dream of Nigerian government and Nigerians for food security. If Nigeria is really serious food security, these challenges must be challenges to be tackled include but not limited to: lack of torage facilities, poor amenities and infrastructures, poor knowledge of moorn a gricultural practices, lack of adequate modern farm implement, lack of adequate capital, poor market pricing system, and unfavorable land holding pattern Land is natural resources where agricultural activities are carried out, the extent to which this land is available for usage has effect on the use of and the form of agricultural system practice and the socioeconomic return from this practice. Base of this regard, there arise the need to take the issue of land holding pattern and land fragmentation of the farming populace very important for optimum productivity. Many fund and activities, as well as policies had been effected by government and concerned NGOs to resuscitate the hailing agricultural sector but all their actives and actions have always prove abortive. Many has also criticized that the one of the reasons why the nations agricultural sector is till in its present predicament is because of wrong policy making and lack of direction In policy implementation. Conducting this research will enable individual farm household understand its environment and how it can take to improve the family socio-economic status. The result will also a the fas understand the effect of land holding pattern on the nation's gricultural sector and the various problems facing the arming populace at the grass rot and how they can make reliable and adequate policy to solve the problems. It will lso assist in the area of policy implementation by giving a direction on how to reach the farming household in the grass root and al so to serve as reference for future research. North Local Government Yearly Publication 2008)

\section{Methods of Data Collection} statistical reports and bulletins.
Sampling Techniques

ling techniques were used in selecting for this study. In the first stage one village s randomly selected from the 16 political words in the Local Government Area The second stage involves randomly selection of 7 farming households in the selected villages. The total number of respondents for this study is 112 sampled respondents.

\section{Methods of Data Analysis}

Both descriptive and inferential statistics were used to analyze the data collected. Descriptive statistics such as frequency tables, means and percentage was used to describe the socio-economic characteristics of the respondents and forms of agricultural practices adopted by farming households. The inferential statistics such as Ordinary Least Square (OLS), Stochastic Frontier Production funct the level of farm-land fragmentation, pattern of andholding and relationship landholding and productivity
of the farming households.

\section{Model Specificatio}

Function

and Coelli (1995), the stochastic production in arable crop production among is specified as follows.

In $\mathrm{Qi}=\mathrm{b} 0+\mathrm{b} 1 \operatorname{In} \mathrm{X} 1+\mathrm{b} 2 \operatorname{In} \mathrm{X} 2+\mathrm{b} 3 \operatorname{In} \mathrm{X} 3+\mathrm{b} 4 \operatorname{In} \mathrm{X} 4+\mathrm{Vi}-$ Ui........

$\mathrm{Q}=$ Output measured as the gross value of all crops harvested including those consumed at home.

$\mathrm{X} 1=$ Farm size $($ hectares $)$

$\mathrm{X} 2=$ Hired labour (manday)

X3 =Family labour (manday)

$\mathrm{X} 4=$ Cost of intermediate materials such as seed, agrochemical, etc $(\mathrm{N})$

$1=$ Parameter associated with the respective production input which except for the intercept term (bo), epresent partial prodiction elasticity with respect to the associated variable.

$\mathrm{Ui}=\mathrm{Is}$ the non-negative random variable associated with technical inefficiency across farming households. The parameters of the stochastic production function in (3) estimated by the limdep econometric software while the technical efficiency of the ith farming household were estimated for each farm household as follows.

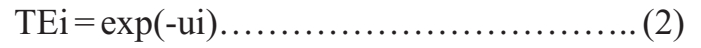

\section{Determinants on Technical Efficiency of Food Crop} Farmers

To examine the influence of landholding patterns and resource endowment on technical efficiency, the following

$\mathrm{TE}=\mathrm{f}(\mathrm{Z1}, \mathrm{Z2}$

$. . \mathrm{k})$

Where: $\mathrm{TE}=$ Technical efficiency level of the ith farming household

$\mathrm{Z1}=$ Farm size $(\mathrm{Ha})$

$\mathrm{Z} 2$ = Extent of farm fragmentation measured by the Simpson Index (S. I), which following Blare, et al (1992) is computed as:

S.I $=1-\frac{\sum A_{i}^{2}}{A^{2}}$

$\mathrm{A}^{2}$

Where: Ai is the area of the ith lot or farm (ha) and $\mathrm{A}=\sum \mathrm{A}$ is the total area cultivated during the agricultural season. Simpson index is a value between 0 and 1 , if the index zero, it implies complete land consolidation (i.e only on larm parcel was cultivated). The index approach a value of equal size. (Blare et 1992).

$\mathrm{Z} 3=$ Distance of farm from home $(\mathrm{km})$

$Z 4=$ Farming experience of household head (years)

$Z 5$-Total credits obtained from formal sources $(N)$

$\mathrm{Z7}=$ Educational level of house head (years)

$\mathrm{Z} 8=$ Age of household head (years) in cultivation of arable crops while som Gage in live stock and fish farming. The Local Geople from Oke-Ona, (ake is one of the mbanguage with Egba dialect. Olumo rock .

Primary data were used for this study through the used of a structured questionnaire, to obtain information about socio-economic status of farmers, type of agricultura system practice, form of land holding system and how their productivity is influenced by all these factors. While secondary data were obtained from past projects, journals, 


\section{RESULTS AND DISCUSSION}

Table 1: Demographic and Non-Demographic Variables of the Farming Households

\begin{tabular}{|c|c|c|c|}
\hline Items & Frequency & Percentage & $\begin{array}{l}\text { Cumulative } \\
\text { Percentage }\end{array}$ \\
\hline \multicolumn{4}{|l|}{ Sex } \\
\hline Male & 88 & 78.6 & 78.6 \\
\hline Female & 24 & 21.4 & 100.0 \\
\hline \multicolumn{4}{|l|}{ Marital Status } \\
\hline Single & 16 & 14.3 & 14.3 \\
\hline Married & 83 & 74.1 & 88.4 \\
\hline Widow & 13 & 11.6 & 100 \\
\hline \multicolumn{4}{|l|}{ Educational Level } \\
\hline Formal & 15 & 13.4 & 13.4 \\
\hline Informal & 97 & 86.6 & 100.0 \\
\hline \multicolumn{4}{|l|}{ Occupation } \\
\hline Farming & 77 & 68.8 & 68.8 \\
\hline Civil service & 19 & 17.0 & 85.7 \\
\hline Trading & 16 & 14.3 & 100.0 \\
\hline \multicolumn{4}{|l|}{ Farm Involvement } \\
\hline Fulltime & 83 & 74.1 & 74.1 \\
\hline Part-time & 29 & 25.9 & 100.0 \\
\hline \multicolumn{4}{|l|}{ Residential Building } \\
\hline Brick house & 41 & 36.6 & 36.6 \\
\hline Block house & 71 & 63.4 & 100.0 \\
\hline \multicolumn{4}{|l|}{$\begin{array}{l}\text { Residential Building } \\
\text { ownership }\end{array}$} \\
\hline Household head & 66 & 58.9 & 58.9 \\
\hline Rented & 21 & 18.8 & 77.7 \\
\hline Extended family & 25 & 22.3 & 100.0 \\
\hline \multicolumn{4}{|l|}{ Land Acquisition } \\
\hline Inherited & 89 & 79.5 & 79.5 \\
\hline Purchased & 14 & 12.5 & 92.0 \\
\hline Leased & 9 & 8.0 & 100.0 \\
\hline Commercial bank & 9 & 8 & 8 \\
\hline Cooperatives & 48 & 42.9 & 50.9 \\
\hline Friends and family & 35 & 31.3 & 82.2 \\
\hline None & 20 & 17.8 & 100 \\
\hline \multicolumn{4}{|c|}{ Hired Labour Quantity } \\
\hline $1-9$ & 21 & 18.8 & 18.8 \\
\hline $10-19$ & 54 & 48.2 & 67 \\
\hline Above 20 & 29 & 25.9 & 92.9 \\
\hline None & 8 & 7.1 & 100.0 \\
\hline \multicolumn{4}{|l|}{ Average Monthly } \\
\hline \multicolumn{4}{|l|}{ Income (N) } \\
\hline $1000-5000$ & 1 & 0.9 & 0.9 \\
\hline $5001-10000$ & 58 & 51.8 & 52.7 \\
\hline $10001-15000$ & 23 & 20.5 & 73.2 \\
\hline $15001-20000$ & 30 & 26.8 & 100.0 \\
\hline
\end{tabular}

$\mathrm{A}_{\mathrm{SN}}$

P-ISSN 2536-6904, E-ISSN 2705-2761 African Journal of Science \& Nature Vol. 10, 114-122 (2020)

Age of the family heads

$<30$ years

$30-40$

$41-50$

$>50$

Farming Exp. (years)

$<10$

$10-20$

21-30

$>30$

Farm Size (ha)

$1-<2$

$>2$

Farm Distance (km)

$1.01-1.50$

$1.51-2.00$

$>2.00$

Source: Field Survey 2019

$\begin{array}{cc}15.2 & 15.2 \\ 22.3 & 37.5 \\ 19.6 & 57.1 \\ 42.9 & 100.0\end{array}$

00.0

$\begin{array}{ll}4.3 & 14.3 \\ 38.4 & 52.7\end{array}$

$\begin{array}{ll}14.3 & 52.7 \\ 42.9 & 95.5 \\ 4.5 & 100.0\end{array}$

$4.5-100.0$

$58.9-58.9$

$34 \quad 92.8$

$7.1-100.0$

$3.4+13.4$

$\begin{array}{ll}25.9 & 25.9 \\ 33.9 & 73.2\end{array}$

26.8

100

Demographic and Non-Demographic

characteristics of sampled farming households

The findings in Table 1 showed the demographic and non-demographic variables of the farming households. The sex distribution showed that $78.6 \%$ of respondents are male, while $21.4 \%$ are female, this may be due to the fact that agricultural require lots on energy and thus it is dominated by males in Nigeria, and the study area is not an exception of this, as agriculture is considered to be male occupation. $74.1 \%$ of respondents are married while $11.6 \%$ are single. The fact that majority of farmers in study area are married means that farmers in the area have family responsibility to cater for, and also sugests tha mo

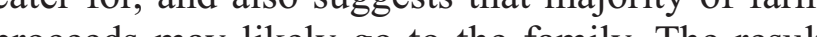
proceds may hely go to the fally. The result further showed that $86.6 \%$ of respondents have informal education, while $13.4 \%$ have informal education. This implies that majority of farmers are illiterate, and would lack modern agricultural practices and techniques and would have limited access to information on new agricultural innovations. In term of religion, $66.1 \%$ of respondents are Christians, $33.9 \%$ of respondent are Muslims. This implies that farmers in the study area have religion anfluence of religion increases the A religion increases the land fragmentation and scarcity of land for large farming activities. $68.8 \%$ of respondents are farmers, while $17.0 \%$ are civil servant, $14.3 \%$ are into trading. This implies that study area is dominated by farmers who take farming as their main occupation and $74.1 \%$ are in to full time farming, $25.9 \%$ are into part -time farming. This implies that majority of farmers have farming as their only source of livelihood and thus devote their active hours to farming as a full time job. Concerning farmers' welfare, 58.9 of respondents owned houses, while $18.8 \%$ respondents rented houses, while 22.3 leave in extended family house. This implies that majority of farmers in study are have been able to provide shelter for their family buy building their own house $79.5 \%$ of respondents acquire land through inheritance, while $12.5 \%$ is through purchasing, and 8.0 got land though easing. This imper leasing. This implies that the land used by farmer is passed from generation to generation through inheritance. $14.3 \%$ of respondents obtained loan from commercial banks, $54.5 \%$ through cooperative, 68.8 through friends and family. This implies that farmers in the study area don't patronize commercial banks to obtain capital This may be due to the formal and strict process involve in obtain loan from these banks.

The average monthly income revealed that $51.8 \%$ 
respectively falls between 5001-10,000 months. $26.8 \%$ fall between $15,000-10,000$. This is an evidence that farmers in Nigeria earn less and hence, the bases for their economy vulnerability. Most farmers (58.1\%) are between 30 - 50 years with above $1-2$ hectares of land and above 50 years is $42.9 \%$. This implies that it is only grown adults that engage in farming in the study area. This may be due to the fact that the youth in the study area will we the want to State capital with $52.7 \%$ having farming
experience of between $10-20$ years. Farmland

\section{Table 2: Simpson Index Estimate of the Land Holding of Respondents}

\begin{tabular}{lccc}
\hline \multicolumn{1}{c}{ Simpson Index } & Frequency & Percentage & Cumulative Percentage \\
\hline 0.00 & 84 & 75 & 75 \\
$0.01-0.50$ & 12 & 10.7 & 85.7 \\
0.51 or more & 16 & 14.3 & 100 \\
Total & $\mathbf{1 1 2}$ & $\mathbf{1 0 0}$ & \\
\hline
\end{tabular}

Source: Field Survey, 2019

As shown in Table 2, a value of zero indicates complete land consolidation. (i.e, the operation of only one farm parcel, while a value of un ( confirms acute farm fragmentation (farms with several parcels) among the study sample. (Blarel et al (1992). Majority (75\%) of the farmers in the study area operated complete land consolidation. The estimated Simpson index for these farmers was zero. The remaining $25 \%$ were found to operate relatively scattered farm land. This practice has the implication of reducing the travel time between field their by increasing labour productivity and lowering the transportation cost for inputs and outputs.

Determinants of Productivity and Technical Efficiency of Food Crop Farmer

Data in Table 3shows that the coefficient of farm size is positive and significant at $0.5(5 \%)$. This implies that it has efficiency increasing effect. Hired labour and cost of intermediate materials such as seed, agro-chemical etc. are positive and significant effect on efficiency at $0.5,(5 \%)$ respectively, signifying that having access to these variables will increase efficiency. The coefficient of farm size is negative and also significant at $10 \%$ This ine This implies that decrease in farm size of land fragmentation index is positive and also have distribution revealed that $34 \%$ have access to $1-<2$ ha, $7.1 \%$ have access to $>2$ ha. This implies that farmers in the study area were predominantly peasant or small - scale farmers, and this will prevent them from taking advantage of economics of size and mechanized farming, hence lowering their productivity and distance of farm plots and his result in low income earning. This occurs as a result of inadequate access to land which make them involved mostly in mixed cropping.

significant on the inefficiency of farmland, increase in this indicate decrease in fragmentation of farmland by $1 \%$, decrease technical inefficiency by 0.004 . This is contrary to Tan (2005) that land fragmentation creates efficiency. The coefficient of distance of farm from residence is positive and distance of farm from residence is positive and significant as $10 \%$ and also coefficient of farming
experience and total credit obtained from formal sources are negative and significant effect on inefficiency, signifying that increase in farming experience reduces efficiency and increase in total credit obtained from formal sources reduces efficiency. Reduction in technical efficiency with increase in year of farming experience is contrary to apriori expectation. However, this could be due apriori expectation. However, this could be due to exper reliance on the acquired experience at the expense of new innovations. This finding is in consonance with that of Ogundari and Ojo (2007). Gender of household head is positive an significant at $1 \%$, while education of household head is positive but with no significant effect on production, Age of respondent is positively significant at $5 \%$. Cost of intermediate materials is positive and significant at $10 \%$. The coefficient of farm size is positively significant at $0.5(5 \%)$. This implies that it has efficiency increasing Hired low it hect. and statistically significant at 10 positive and statistically significant at 10 percent
respectively,

Table 3: Maximum Likelihood Estimate (MLE) of Stochastic Production Frontier

Natural log factors

MLE Coefficient

\begin{tabular}{|c|c|c|}
\hline Constant & $\begin{array}{l}3.825^{*} \\
(5.066)\end{array}$ & $\begin{array}{l}4.842 * * \\
(17.53)\end{array}$ \\
\hline Farm Size & $\begin{array}{l}0.983 * * \\
(29.316)\end{array}$ & $\begin{array}{l}9.535^{* *} \\
(61.45)\end{array}$ \\
\hline Hired labor & $\begin{array}{l}9.187^{*} \\
(1.574)\end{array}$ & $\begin{array}{l}0.357^{* *} \\
(17.197)\end{array}$ \\
\hline Family labour & $\begin{array}{l}0.359^{*} \\
(3.211)\end{array}$ & $\begin{array}{l}-9.837^{*} \\
(2.639)\end{array}$ \\
\hline Cost of intermediate materials & $\begin{array}{l}8.753^{*} \\
(2.717)\end{array}$ & $\begin{array}{l}0.165^{* *} \\
(15.148)\end{array}$ \\
\hline Inefficiency model constant & & $\begin{array}{c}3.565^{*} \\
(3.11)\end{array}$ \\
\hline Farm experience & & $\begin{array}{l}-1815^{*} \\
(-3.634)\end{array}$ \\
\hline Extent of farm fragmentation & & $\begin{array}{l}1.976^{* * *} \\
(2.254)\end{array}$ \\
\hline Distance of farm from home & & $\begin{array}{c}-3.697^{* *} \\
(1.394)\end{array}$ \\
\hline $\begin{array}{l}\text { Farming experience of house hold } \\
\text { head }\end{array}$ & & $\begin{array}{c}-1.475^{* * *} \\
(2.164)\end{array}$ \\
\hline Total credit obtained & & $\begin{array}{l}-7.052^{* *} \\
(-1.95)\end{array}$ \\
\hline Gender of household head & & $\begin{array}{c}3.588 \\
(27.623)\end{array}$ \\
\hline Age of respondents & & $7.558 * *$ \\
\hline Log likelihood & 0.1631 & 67.226 \\
\hline Sigma Square & & $\begin{array}{c}0.545 \\
(3.518)\end{array}$ \\
\hline Gamma & & $\begin{array}{c}0.999 \\
(94.37)\end{array}$ \\
\hline
\end{tabular}

Figures in parenthesis are the $t$ values of estimate. $* * *=$ significant at $1 \%, * *=$ Significant at $5 \%, *=$ Significant at $10 \%$ Source: Field Survey, 2019

The finding and data in Table 4 revealed that predicted technical efficiencies range between 0.10 $(10 \%)$ and $0.90(90 \%)$ while the mean technical efficiency of the entire sample was estimated at $0.84 \%)$. Table 4.1 .24 shows that $17.64 \%$ of the 60\% of the sanpled fameers are below and $70 \%$ of the sampled farmers are above, indicating that majority $(70 \%)$ of the farmers are close to the production frontier. The mean of technical efficiency (84\%) signifies that there exit $16 \%$ potential for farmers to increase their production through the existing level of resources and technology by operat level, farmers can increase their production by an level, farmers can increase their production by an average of $16 \%$ with the available farm resources
and technology. 


\section{Table 4: Technical Efficiency Levels of the Sampled Farming Household}

\begin{tabular}{lcc}
\hline Decile range & Frequency & Percentage \\
\hline $0.10-0.19$ & 1 & 0.89 \\
$0.20-0.79$ & - & - \\
$0.30-0.39$ & - & - \\
$0.40-0.49$ & 5 & 4.46 \\
$0.50-0.59$ & 2 & 1.79 \\
$0.60-0.69$ & 4 & 3.57 \\
$0.70-0.79$ & 23 & 20.54 \\
$0.80-0.89$ & 22 & 19.64 \\
$0.90-0.99$ & 55 & 49.11 \\
Total & 112 & 100 \\
\hline
\end{tabular}

Mean Technical Efficiency $=0.84$, Minimum $=0.10(10 \%)$, Maximum $=0.90(90 \%)$

Source: Field Survey, 2019

\section{CONCLUSION AND RECOMMENDATIONS}

Base on the findings of this research work, the following conclusions could be drawn: majority of farmers are male, farmers have access to land through inheritance, and also most of farmers could not access loans from financial intuitions. This could be due to strict conditions for granting of loan adopted by these financial institutions. The findings also revealed that farmers face difficulties in accessing land and thus they farm on available scattered farm land which will not encourage commercial farming and practice of mecharized com farming. Farner. still considered the use of hired abour as option. Farmers use less of family labour, could be because children will be at school during active farming hours. Based on the findings, it is therefore recommended that:

(i) Government should make policies that will make access to land more easier to farmers, so that they can cultivate on large parcel of land other than the ones inherited.

(ii) Government should create and execute good agricultural policies that will encourage young graduate to go into farming. young graduate to go into arming.

(iii) Government should encourage mechanized (iv) Policies that will make loan more accessible to farmers should be introduced.

(v) Land consolidation should be encouraged among farmers.

(vi) Youth should be encouraged to go in to farming. Instead of looking for white colla jobs in the cities.

\section{REFERENCES}

folayan, A. (1998). A Geography of Nigerian Development. Heinnemann Educational Books. 1978.

Battese. G. E and Coelli, T. J (1995), "A Model for Technical Inefficiency Effect in a Stochastic Frontier Production Function for Panel Data"Empirical Economics. 14

DFID (2004), "Rural Urban Development Case Study-Nigeria" Oxford Policy Management of Immigration 22.

Doner, P. and Kanel, D, (1997). The Economic Case for Land Reform: Employment, Income Distribution and Productivity. Reprint No. 74. Land Tenure Center, University of Winscosin, Madison.
Famoriyo B (1996), Land Tenure and Agriculture Development in Nigeria, Nigerian Institute of Social and Economic Research, Ibadan.

Ogundari, K and Ojo, S. O (2007). "Economics Efficiency of Small Scale Food Crop Production In Nigeria. Stochastic Frontier and Appliance. Journal of Social Sciences $14(2): 123-13$
Tan, S (2005). Land Fragmentation and Rice Production. A case study of small farms in Jiangxi province, China. Ph.D. Thesis, Wagenigen University 